Research articles

\title{
Male and female students' mathematical reasoning skills in solving trigonometry problems
}

\author{
Suparman ${ }^{1}$, Al Jupri ${ }^{1}$, Edwin Musdi ${ }^{2}$, Nonong Amalita ${ }^{2}$, Maximus Tamur ${ }^{3}$, Jihe Chen ${ }^{4}$
}

\begin{abstract}
Abstrak Beberapa studi sudah dilakukan untuk menguji kemampuan penalaran matematis siswa laki-laki dan perempuan di berbagai topik matematika. Namun, studi-studi yang fokus pada kemampuan penalaran matematis di topik trigonometri ditinjau dari perspektif gender masih belum banyak. Penelitian kuantitatif ini bertujuan untuk mendeskripsikan dan membandingkan kemampuan penalaran matematis siswa laki-laki dan perempuan dalam menyelesaikan masalah-masalah trigonometri. Studi ini melibatkan siswa sekolah menengah yang diberi tes kemampuan penalaran matematis. Tes tersebut sudah divalidasi secara teoritis dan empiris. Hasil tes tersebut dikategorikan menggunakan rubrik capaian penalaran matematis dan dianalisis menggunakan uji Mann-Whitney atau uji t. Hasil menunjukkan bahwa secara keseluruhan kemampuan penalaran matematis siswa lakilaki dan perempuan belum tinggi. Siswa tersebut kurang mampu dalam menemukan pola hubungan, mengajukan dugaan, dan mengeneralisasi pernyataan, tetapi mereka memiliki kemampuan yang sedang dalam memverifikasi kebenaran suatu argumen. Selanjutnya, siswa laki-laki dan siswa perempuan tidak berbeda secara signifikan dalam aspek kemampuan penalaran matematis. Temuan ini memberikan titik awal yang penting untuk meningkatkan kemampuan penalaran matematis siswa dalam pembelajaran trigonometri.
\end{abstract}

\section{Kata kunci Gender, Kemampuan penalaran, Masalah trigonometri}

Abstract Several studies have examined mathematical reasoning skills (MRS) of male and female students in various mathematics topics. However, there were still not many studies, which focus on MRS in trigonometry topics in terms of gender perspectives. Therefore, this quantitative study aims to describe and compare the MRS of male and female students in solving trigonometry problems. This study involved secondary school students who were given an MRS test. The test has been validated theoretically and empirically. The results of the test were classified using the rubric of MRS achievement and analyzed using the Mann-Whitney test or t-test. The results revealed that the overall MRS of male and female students was low. The students lacked skills in finding a relationship pattern, proposing a conjecture, and generalizing the statement, but they had moderate skills in verifying the truth of an argument. Furthermore, the male and female students were not significantly different in the aspects of MRS. The findings provide important starting points to enhance students' MRS in the teaching and learning of trigonometry.

Keywords Gender, Mathematical reasoning skill, Trigonometry problem

\footnotetext{
${ }^{1}$ Department of Mathematics Education, Universitas Pendidikan Indonesia, Jln. Dr. Setiabudi No. 229, Bandung, Indonesia, arman95@upi.edu

2 Study Program of Mathematics Education, Universitas Negeri Padang, Jln. Prof. Dr. Hamka., Padang, Indonesia

${ }^{3}$ Universitas Katolik Santu Paulus Ruteng, Jln. Jend. A Yani No. 10, Ruteng, Indonesia

${ }^{4}$ Department of Mathematics and Statistics, Guangxi Normal University, China
} 


\section{Introduction}

One of the mathematics learning goals is that students can solve problems both routine and non-routine problems. Mathematical reasoning skills (MRS) have a critical role in supporting students' skills to solve a problem, especially non-routine problems. Several studies showed that reasoning skills and problem-solving skills have a significant positive correlation (Buckley, Seery, \& Canty, 2019; Chang, 2010; Wong, 2017). When students' reasoning skills improve, students can solve the problems they face (Ersoy \& Bal-İncebacak, 2017; Rosdiana, Budayasa, \& Lukito, 2019). Students who have high problem-solving skills tend to be able to solve any problem that arises from changing situations and conditions (Suparman et al., 2021). Therefore, mathematics learning should be able to facilitate students to develop and improve their MRS. Several studies reveal that mathematics is a male domain (Brandell, Leder, \& Nyström, 2007; Brandell \& Staberg, 2008; Mendick, 2005). Also, other studies show that male students' MRS is higher than female students in mathematics topics generally (Erdem \& Soylu, 2017) and in geometry topics (Dhlamini et al., 2019; Kadarisma et al., 2019; Setiawan \& Sa'dijah, 2020). However, different studies unravel that female students' MRS is higher than male students in mathematics topics in general (Misu, Hasnawati, \& Rahim, 2019; Salam \& Salim, 2020) and algebra topics (Rodiah \& Triyana, 2019). These findings indicate an inconsistency of students' MRS in mathematics topics in terms of gender perspectives. Therefore, it is crucial to examine whether inconsistency of students' MRS based on gender also exists in other topics such as trigonometry. As a consequence, this study is expected to help mathematics teachers design instructional activities in the trigonometry topic, which support gender-based students' MRS.

The trigonometry topic is selected in this study because several studies showed that the students' errors rate in solving trigonometry problems tends to be high. The errors include; do not understand the problems given, do not master the basic concept of trigonometry, perform basic arithmetic operations, determine the formula to solve the problem and write the final answer (Altiner \& Dogan, 2018; Hidayati, 2020; Sartika \& Fatmanissa, 2020, Satriani et al., 2020; Usman \& Hussaini, 2017; Wahyuni \& Widayanti, 2020). The studies about students' MRS from the gender perspective have been conducted. However, it focuses on students' MRS in general mathematics topics (Erdem \& Soylu, 2017; Misu et al., 2019; Salam \& Salim, 2020), geometry topic (Kadarisma et al., 2019; Rosdiana et al., 2019; Setiawan \& Sa'dijah, 2020), and algebra topic (Karunika, Kusmayadi, \& Fitrana, 2019; Rodiah \& Triyana, 2019). Meanwhile, this study focuses on male and female students' MRS in trigonometry topic. Although relevant studies on students' MRS in trigonometry have been conducted (e.g., Rokhima, Kusmayadi, \& Fitriana, 2019), those studies only focus on basic trigonometry. However, this study focuses on trigonometry identity, sine and cosine law, and trigonometry function because some studies (e.g., Altiner \& Dogan, 2018) reported that students still have errors when dealing with these trigonometry topics.

The recent study aims to describe and compare male and female students' MRS in solving trigonometry problems. The research questions are: (1) is there any significant difference of MRS between male students and female students in solving trigonometry problems? (2) how is the achievement level of male and female students' MRS in solving trigonometry problems? 


\section{Theoretical review}

Reasoning skills are high thinking abilities represented during the problem-solving process (Yildirim, 2000). In this case, mathematical reasoning skills represent problem-solving activities involving inductive, deductive, abductive, associative, and inferential thinking processes (Erdem \& Soylu, 2017; Morris, 2002), and a thinking process in understanding the ideas and concepts inherent in a procedure (Bieda et al., 2014). In some literature, MRS consists of several abilities such as finding a relationship pattern, proposing a conjecture, generalizing a statement, convincing, reflecting, proving the truth of an argument, and making connections, abstraction, and specialization (Bjuland, 2007; Breen \& O'Shea, 2011; NCTM, 2000). It is important for predicting students' future success in mastering mathematics at a high level (Rich \& Brendefur, 2019), and students' future career success (Marchis, 2013).

In this study, we refer to four indicators of MRS to measure male and female students' MRS. These indicators are (1) proposing a conjecture, (2) verifying the truth of an argument (NCTM, 2000), (3) finding a relationship pattern (Breen \& O'Shea, 2011), and (4) generalizing a statement (Bjuland, 2007). These indicators are selected in this study because some reports reveal that the achievement of students' MRS in proposing a conjecture, finding a relationship pattern, verifying the truth of an argument, and generalizing a statement is lower than the achievement of students' MRS in other indicators of MRS (Erdem \& Soylu, 2017; Dhlamini et al., 2019; Salam \& Salim, 2020).

Trigonometry is one of the mathematics fields. It is one of the applicable mathematics topics since it has many applications with other subjects such as Physics, Engineering, Chemistry, and much more (Goel \& Elstak, 2015). Therefore, this topic is interesting to be studied. Also, the trigonometry topic can support this study to measure students' MRS by applying realistic problems in daily life. Some students reveal that this topic is a daunting topic to be learned due to some bizarre symbols such as $\sin \theta$ and $\cos \theta$ (Goel \& Elstak, 2015). Moreover, several empirical studies reveal that most students make errors in solving trigonometry problems (Altiner \& Dogan, 2018; Usman \& Hussaini, 2017). Therefore, this topic is selected to measure male and female students' MRS in this study.

In the trigonometry topic, there are some sub-topics such as trigonometry identity, sine and cosine law, trigonometry function, trigonometry equation, and trigonometry inequality. The trigonometry identity is chosen to measure students' MRS in finding a relationship pattern. In addition, to measure students' MRS in proposing a conjecture and verifying the truth of an argument, sine and cosine laws are selected. The trigonometry function is selected as a material to measure students' MRS in generalizing a statement. These trigonometry topics were selected because students still carried out many errors in these topics reported by prior studies (Altiner \& Dogan, 2018; Hidayati, 2020; Sartika \& Fatmanissa, 2020, Satriani et al., 2020; Usman \& Hussaini, 2017; Wahyuni \& Widayanti, 2020). So, every sub-topic in the trigonometry established in this study represents every indicator of MRS selected in this study (See Table 1). Also, to measure the achievement of students' MRS on each sub-topic of trigonometry, the design of the MRS's scoring rubric will accommodate it (See Table 2).

\section{Methods}

This study employed the descriptive and comparative research design with a quantitative approach (Gall, Gall, \& Borg, 2003). There were four steps to conduct this study. Firstly, we designed the MRS test items (See Table 1). It was designed based on the established indicators 
of MRS (Bjuland, 2007; Breen \& O'Shea, 2011; NCTM, 2000), which consist of four trigonometry problems within the topics such as trigonometry identity, sine and cosine law, and trigonometry function.

Secondly, we validated the test theoretically and empirically. Theoretically, two experts in mathematics education were involved in the validation process in which they verified and justified the MRS test items based on the content and language. It resulted in a valid and eligible test. Also, sixty tenth-grade students were involved in the empirical validation process. The results showed that the test had a significant differentiator index. Moreover, three problems had a moderate difficulty index, and one problem had a high difficulty index. Also, the reliability test showed that the Alpha Cronbach coefficient was 0,66. These findings indicate that the test was reliable and eligible to be used as an instrument to measure MRS in this study (Gliem \& Gliem, 2003; Shelby, 2011; Vaske, Beaman, \& Sponarski, 2016).

Table 1. The developed test for MRS

\begin{tabular}{|c|c|c|}
\hline Item & Indicator & Problem \\
\hline 1 & $\begin{array}{l}\text { Finding a } \\
\text { relationship } \\
\text { pattern }\end{array}$ & $\begin{array}{l}\text { Given } \alpha_{1}, \alpha_{2}, \ldots, \alpha_{n} \text { are one of angles in } \mathrm{n} \text { arbitrary triangles. If } p= \\
\sec ^{2} \alpha_{1}+\csc ^{2} \alpha_{n}+\sec ^{2} \alpha_{2}+\csc ^{2} \alpha_{n-1}+\cdots+\sec ^{2} \alpha_{n}+\csc ^{2} \alpha_{1} \text { and } \\
q=\tan ^{2} \alpha_{1}+\cot ^{2} \alpha_{n}+\tan ^{2} \alpha_{2}+\cot ^{2} \alpha_{n-1}+\cdots+\tan ^{2} \alpha_{n}+ \\
\cot ^{2} \alpha_{1} \text { then determine the value of } p-q\end{array}$ \\
\hline 2 & $\begin{array}{l}\text { Proposing a } \\
\text { conjecture }\end{array}$ & $\begin{array}{l}\text { There are two ponds of catfish types Alpha and Beta, which are in the } \\
\text { form of an arbitrary triangle. The endpoints of catfish pond type Alpha } \\
\text { are } \mathrm{P}, \mathrm{Q} \text {, and R, while the endpoints of catfish pond type Beta are K, M, } \\
\text { and N. If the length of PQ, QR, and PR is respectively } 7 \mathrm{~m}, 8 \mathrm{~m} \text {, and } 9 \\
\mathrm{~m} \text {, while the length of KM, MN, and KN are respectively } 6 \mathrm{~m}, 8 \mathrm{~m} \text {, and } \\
13 \mathrm{~m} \text {, so which type of catfish pond has the vertex with the largest angle } \\
\text { size? Mention the point and give the reason! }\end{array}$ \\
\hline 3 & $\begin{array}{l}\text { Verifying the } \\
\text { truth of the } \\
\text { statement }\end{array}$ & $\begin{array}{l}\text { Amanda stands in a place on the side of a straight and high-flowing } \\
\text { river. She observes the Pine and Mahogany trees that are on the other } \\
\text { sides of the river. The Pine tree is a right cross from her, and the }\end{array}$ \\
\hline & & $\begin{array}{l}\text { distance of the Pine and Mahogany trees is } 4 \sqrt{6} \mathrm{~m} \text {, and the size of } \\
\text { Amanda's viewpoint angle on two trees is } 30^{\circ} \text {. There is no connecting } \\
\text { bridge to cross the river, and around Amanda, there is only a wooden } \\
\text { beam with the size of } 18 \mathrm{~m} \times 30 \mathrm{~cm} \times 10 \mathrm{~cm} \text {. Suddenly, Arman comes, } \\
\text { there is dialogue like the following: }\end{array}$ \\
\hline & & Arman: Do you want to cross this river? \\
\hline & & $\begin{array}{l}\text { Amanda: Yes, but I am confusing about whether the wooden beam can } \\
\text { be used to cross this river. What do you think? }\end{array}$ \\
\hline & & Arman: I think that this wooden beam can be used to cross this river. \\
\hline & & $\begin{array}{l}\text { Based on the above dialogue, check the truth of Arman's statement and } \\
\text { conclude the problem! }\end{array}$ \\
\hline \multirow[t]{6}{*}{4} & \multirow{6}{*}{$\begin{array}{l}\text { Generalizing the } \\
\text { statement }\end{array}$} & The characteristics of the cosine function are as follows: \\
\hline & & - Its domain is $D_{g}=\left\{x \mid 0 \leq x \leq \frac{\pi}{2}\right\}$ \\
\hline & & - $\quad$ Its range is $R_{g}=\{y \mid-2 \leq y \leq 4\}$ \\
\hline & & $\begin{array}{l}\text { - The general form of its function is } g(x)=p \cos k x+r \\
\text { - } \quad \mathrm{P} \text { is a positive integer less than } 5\end{array}$ \\
\hline & & - $\quad$ Some points passed through by the curve are $(0,4)$ and $\left(\frac{\pi}{2},-2\right)$ \\
\hline & & $\begin{array}{l}\text { Based on the characteristics above, determine the cosine function. Give } \\
\text { the reason and conclude the problem! }\end{array}$ \\
\hline
\end{tabular}


Thirdly, we administered the test to the 62 tenth-grade students ( 23 males and 39 females, 16-17 years old). The participants were given 120 minutes to solve all of the problems using the paper-based test. They were selected using the purposive sampling technique due to the easy access of place and time in communicating this study to participants.

Table 2. The scoring rubric of the MRS test

\begin{tabular}{|c|c|c|}
\hline Indicator & Scale & Description \\
\hline \multirow{5}{*}{$\begin{array}{l}\text { Finding a } \\
\text { relationship } \\
\text { pattern }\end{array}$} & 0 & No answer \\
\hline & 1 & The pattern found is wrong \\
\hline & 2 & The pattern found is correct but the \\
\hline & 3 & $\begin{array}{l}\text { The pattern found is correct; the principles or concepts used are correct, but } \\
\text { the arithmetic operation is less precise. }\end{array}$ \\
\hline & 4 & $\begin{array}{l}\text { The pattern found is correct, the principles or concepts used are correct, } \\
\text { and the arithmetic operation is precise }\end{array}$ \\
\hline \multirow{5}{*}{$\begin{array}{l}\text { Proposing a } \\
\text { conjecture }\end{array}$} & 0 & No answer \\
\hline & 1 & The conjecture given is wrong \\
\hline & 2 & The conjecture given is correct, but no reason for the conjecture made \\
\hline & 3 & $\begin{array}{l}\text { The conjecture given is correct, there is the reason for the conjecture made, } \\
\text { but it is less precise }\end{array}$ \\
\hline & 4 & $\begin{array}{l}\text { The conjecture given is correct, there is the reason for the conjecture made, } \\
\text { and it is precise }\end{array}$ \\
\hline \multirow{5}{*}{$\begin{array}{l}\text { Verifying } \\
\text { the truth of a } \\
\text { statement }\end{array}$} & 0 & No ar \\
\hline & 1 & Steps in the verification process are wrong or mostly wrong \\
\hline & 2 & $\begin{array}{l}\text { Steps in the verification process are correct but the principles or concepts } \\
\text { used are wrong }\end{array}$ \\
\hline & 3 & $\begin{array}{l}\text { Steps in the verification process are correct, the principles or concepts used } \\
\text { are correct, but the arithmetic operation is less precise }\end{array}$ \\
\hline & 4 & $\begin{array}{l}\text { Steps in the verification process are correct, the principles or concepts used } \\
\text { are correct, and the arithmetic operation is precise }\end{array}$ \\
\hline \multirow{5}{*}{$\begin{array}{l}\text { Generalizing } \\
\text { the } \\
\text { statement }\end{array}$} & 0 & No answer \\
\hline & 1 & Generalization and the process of generalizing is wrong or mostly wrong \\
\hline & 2 & $\begin{array}{l}\text { Generalization is correct but the process of generalizing is wrong or mostly } \\
\text { wrong }\end{array}$ \\
\hline & 3 & $\begin{array}{l}\text { Generalization is correct, but there is a slight error in the process of making } \\
\text { the generalization }\end{array}$ \\
\hline & 4 & $\begin{array}{l}\text { Generalization is correct, and the process of generalizing is correct and } \\
\text { precise }\end{array}$ \\
\hline
\end{tabular}

Fourthly, we analyzed the results of the test. The scoring rubric (Table 2) was used to measure students' MRS. Furthermore, the scoring rubric was arranged according to the Likert scale, which was $0-4$ (Boone \& Boone, 2012; Brown, 2011; Sullivan \& Artino, 2013). Each scale of $0-4$ interpreted the overall students' answers to each question.

The results of the MRS test were measured based on the scoring rubric. Also, the achievement of MRS of male and female students was classified as high $(v>70 \%)$, moderate $(55 \%<v \leq 70 \%)$, and low ( $v \leq 55 \%)$ (Maya, 2011). Furthermore, the comparison test of two means, such as t-test or Mann-Whitney, was applied to compare the MRS of male and female students in trigonometry topics (Fay \& Proschan, 2010; McElduff et al., 2010; De Winter \& Dodou, 2010). The assumption tests such as the data normality and homogeneity tests were checked to establish the comparison test of two means used (de Gois et al., 2020; Gorbunova \& 
Lemeshko, 2012; Rasch, Kubinger, \& Moder, 2011). To analyze the result of the MRS, Microsoft Excel and SPSS version 21 software were used as the tools.

\section{Findings and Discussion}

\section{The male and female students' MRS}

The analysis of the MRS test using the scoring rubric showed that from twenty-three male students, seven students had moderate MRS, and sixteen students had low MRS. Also, from thirty-nine female students, two students had high MRS, seven students had moderate MRS, and thirty students had low MRS.

Table 3. Students' MRS in trigonometry topic

\begin{tabular}{lccccc}
\hline Gender & \multicolumn{2}{c}{ Descriptive statistics } & \multicolumn{2}{c}{$\begin{array}{c}\text { Mathematical reasoning } \\
\text { achievement }\end{array}$} \\
\cline { 2 - 6 } & Mean & Standard deviation & Sample size & Mean of percentage & Category \\
\hline Male & 6,35 & 2,71 & 23 & $39,67 \%$ & Low \\
Female & 5,92 & 3,17 & 39 & $37,02 \%$ & Low \\
\hline
\end{tabular}

Table 3 shows that the overall achievement of male and female students' MRS in solving trigonometry problems was still low. Furthermore, the Shapiro-Wilk test showed that the P-value was more than 0,05 . It means that the data is normal. In addition, Levene's test showed that the P-value was more than 0,05 . It indicates that the variance of data is homogeneous. Because the data was normal and had homogeneous variance, the t-test was carried out to justify any difference between male and female students' MRS significantly (Fay \& Proschan, 2010; McElduff et al., 2010). The results of the t-test are presented in Table 4.

Table 4. The comparison of male and female students' MRS

\begin{tabular}{ccc}
\hline t-value & Degree of Freedom (df) & Sig. (2-tailed) \\
\hline 0,538 & 60 & 0,593 \\
\hline
\end{tabular}

Table 4 reveals that the $\mathrm{p}$-value of $\mathrm{T}$ statistics was more than 0,05 . It indicates that the MRS of male and female students in solving trigonometry problems do not differ significantly. This finding was similar to Salam and Salim (2020); their results showed that the MRS between male and female students in mathematics was not significantly different. Moreover, in solving geometry problems, the MRS between male and female students was also not significantly different (Kadarisma et al., 2019). Therefore, these findings support this study that male and female students' MRS is not significantly different in solving trigonometry problems.

However, Table 3 reveals that female students' MRS were lower than male students' MRS. Similar previous studies also revealed that male students' MRS were higher than female students' MRS in solving mathematics problems (Erdem \& Soylu, 2017) and geometry problems specifically (Kadarisma et al., 2019; Setiawan \& Sa'dijah, 2020). These findings provide strong evidence that the term "mathematics as a male domain" is right. In this context, mathematics as a male domain means that male students have performed better than female students for mathematical skills, especially MRS (Brandell \& Staberg, 2008).

Although this study provides evidence that the MRS is a male domain descriptively, the results of other studies show that male students' MRS was not higher than female students' MRS 
(Misu et al., 2019; Salam \& Salim, 2020). These findings interpret that mathematics as a male domain is not applied absolutely. Factors such as class, ethnicity, and geographical location could make this different study (Yates, 1997). In their study, Yates (1997) reported that in Australia and United Kingdom, female students outperformed male students in mathematics study. Also, socioeconomic status was one factor causing the difference in the mathematical skills of male and female students, specifically MRS (Brandell \& Staberg, 2008). As a consequence, these factors become a determinant part of the different MRS levels in gender issues.

\section{Male and female students' MRS for each indicator}

\section{Finding a relationship pattern}

Table 5. The results of students' MRS in finding a relationship pattern

\begin{tabular}{lccccc}
\hline Gender & \multicolumn{2}{c}{ Descriptive statistics } & \multicolumn{2}{c}{$\begin{array}{c}\text { Mathematical reasoning } \\
\text { achievement }\end{array}$} \\
\cline { 2 - 6 } & Mean & Standard deviation & Sample size & Mean of percentage & Category \\
\hline Male & 0,74 & 0,75 & 23 & $18,48 \%$ & Low \\
Female & 1,00 & 1,24 & 39 & $25 \%$ & Low \\
\hline
\end{tabular}

The achievement of male and female students' MRS in this indicator is presented in Table 5. It shows that male and female students' skill in finding a relationship pattern of the trigonometry identity problem was low. In the previous study, Rodiah and Triyana (2019) showed a similar result that students' skill to analyze mathematics situations using the pattern was low. The low skill of male and female students in finding a relationship pattern could be drawn from the analysis of the achievement of students' skills in solving trigonometry identity problems. Of twenty-three male students, all of them had a low skill in finding a relationship pattern. It indicates that their low skill in finding a relationship pattern makes them difficult to solve the problem. On the other hand, seven female students had a high skill, and thirty-two female students had a low skill in finding a relationship pattern from thirty-nine female students. It means that most female students still have difficulty solving trigonometry identity problems, whereas a small proportion of female students have been able to solve the problem.

The distribution of male and female students' skills in finding a relationship pattern of trigonometry identity problems is presented in Figure 1. It describes those two female students who found the correct pattern, employed the correct principle and concept, and carried out the precise arithmetic operation. As a consequence, they were able to determine the value of $p-q$ correctly. It indicates that they have the high skill to find a relationship pattern in solving trigonometry identity problems. The evidence is presented in Figure 2.

Five female students found the correct pattern and used the correct principle and concept, but they conducted the less precise arithmetic operations. Some studies also reveal that students often made errors in arithmetic operations (Hidayati, 2020; Usman \& Hussaini, 2017). Students' errors in arithmetic operations could be affected by difficulty in conducting basic arithmetic operations such as calculation or computation (Rohimah \& Prabawanto, 2019). Therefore, they were not able to find the precise final answer. It indicates that they have a moderate skill to find a relationship pattern in solving trigonometry identity problems. Four male students and two female students could find the correct pattern; however, they used the wrong principle or concept. This finding was in line with several studies showing that some students often did not 
understand the principle or concept such as theorem or formula used to solve the trigonometry identity problem (Sartika \& Fatmanissa, 2020). Also, nine male students and twelve female students did not get the correct pattern. This can be interpreted that they have a low skill in finding a relationship pattern of a trigonometry identity problem. The evidence is presented in Figure 3.

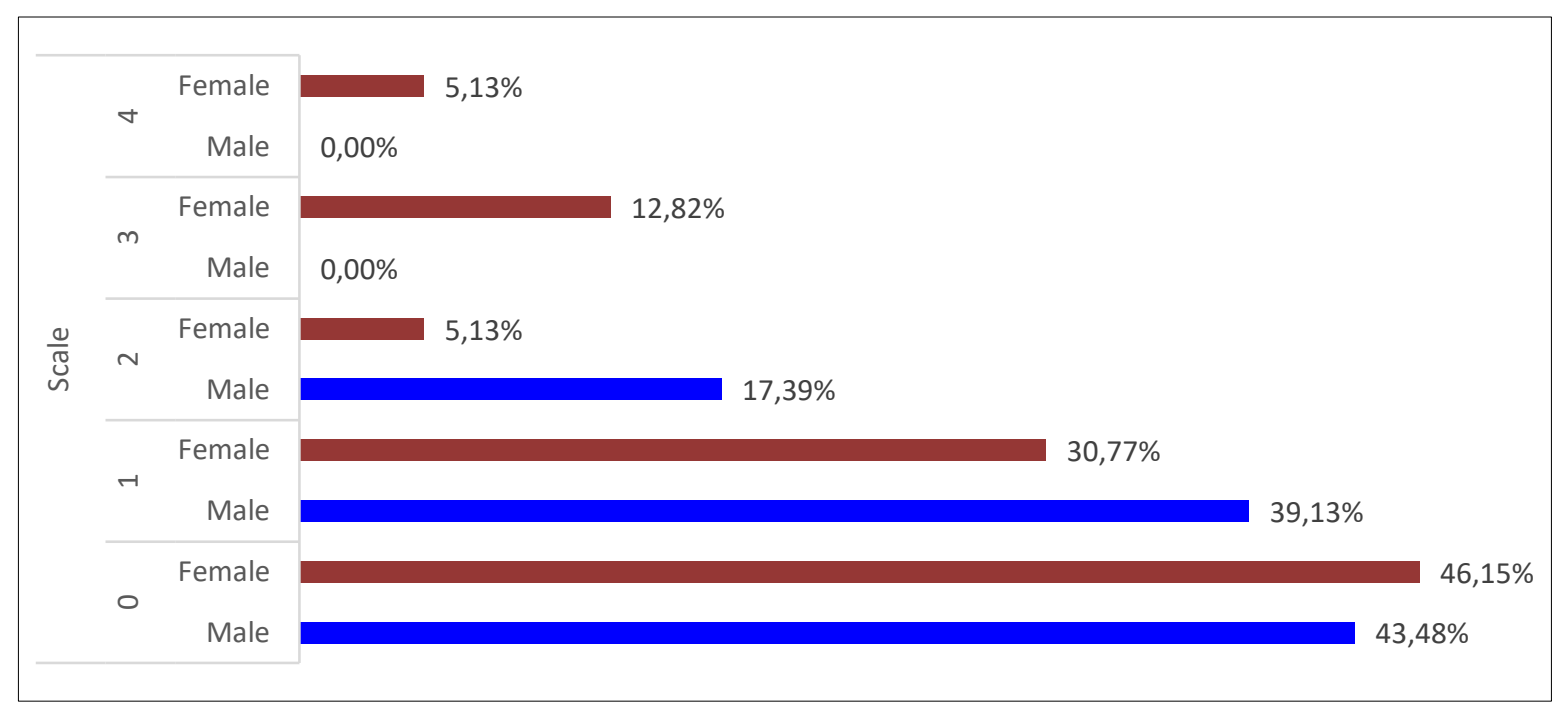

Figure 1. The distribution of students' skills in finding a relationship pattern

$$
\text { (1) } \begin{aligned}
p-a= & \left(\sec ^{2} \alpha_{1}+\csc ^{2} \alpha_{n}+\sec ^{2} \alpha_{2}+\csc ^{2} \alpha_{n-1}+\cdots+\sec ^{2} \alpha_{n}+\csc ^{2} \alpha_{1}\right)-\left(\tan ^{2} \alpha_{1}+\right. \\
& \left.\cot ^{2} \alpha_{n}+\tan ^{2} \alpha_{2}+\cot ^{2} \alpha_{n-1}+\cdots+\tan ^{2} \alpha_{n}+\cot ^{2} \alpha_{1}\right) \\
= & \left(\sec ^{2} \alpha_{1}-\tan ^{2} \alpha_{1}+\sec ^{2} \alpha_{2}-\tan ^{2} \alpha_{2}+\cdots+\sec ^{2} \alpha_{n}-\tan ^{2} \alpha_{n}\right)+\left(\sec ^{2} \alpha_{1}-\right. \\
& \left.\cot ^{2} \alpha_{1}+\csc ^{2} \alpha_{2}-\cot ^{2} \alpha_{2}+\cdots+\csc ^{2} \alpha_{n}-\cot ^{2} \alpha_{n}\right) \\
= & (1+1+\cdots+1)+(1+1+\cdots+1) \\
= & n+n \\
= & 2 n
\end{aligned}
$$

Figure 2. The evidence of female students' answers in solving the trigonometry identity problem

$$
\text { (1) } \begin{aligned}
p & =\sec ^{2} \alpha_{1}+\csc ^{2} \alpha_{n}+\sec ^{2} \alpha_{2}+\csc ^{2} \alpha_{n-1}+\cdots+\sec ^{2} \alpha_{n}+\csc ^{2} \alpha_{1} \\
q & =\tan ^{2} \alpha_{1}+\cot ^{2} \alpha_{n}+\tan ^{2} \alpha_{2}+ \\
& =1+1+1+1 \\
& =r
\end{aligned}
$$

Figure 3. The evidence of male students' answers in solving the trigonometry identity problem

Ten male students and eight-teen female students did not give their answers. This proves that the overall male and female students' skill to find a relationship pattern of trigonometry identity problem was low. Therefore, it is needed an extraordinary effort to enhance students' 
skills in finding a relationship pattern in trigonometry topics, specifically in trigonometry identity topics.

Because of the unnormal data, the Mann-Whitney test was conducted to give the justification of the difference between male and female students' skills in finding a relationship pattern (Fay \& Proschan, 2010; McElduff et al., 2010). The results of the Mann-Whitney test showed that the $p$-value of $U$ statistics was 0,772 , and it was more than 0,05 . This result indicates that male and female students' skills to find a relationship pattern in solving trigonometry identity problem is not different significantly. It could be shown using the same achievement level of male and female students' skills in finding a relationship pattern-which was low. However, descriptively, female students' skill to find a relationship pattern was higher than male students' skill to find a relationship pattern in solving trigonometry identity problems. This finding was supported by the previous studies showing that male students' mathematical skill was lower than female students' mathematical skill in trigonometry topic (Salam \& Salim, 2020).

\section{Proposing a conjecture}

Table 6. The results of students' MRS in proposing a conjecture

\begin{tabular}{lccccc}
\hline Gender & \multicolumn{2}{c}{ Descriptive statistics } & \multicolumn{2}{c}{$\begin{array}{c}\text { Mathematical reasoning } \\
\text { achievement }\end{array}$} \\
\cline { 2 - 6 } & Mean & Standard deviation & Sample size & Mean of percentage & Category \\
\hline Male & 2,00 & 1,24 & 23 & $50 \%$ & Low \\
Female & 2,00 & 1,38 & 39 & $50 \%$ & Low \\
\hline
\end{tabular}

Table 6 reveals that male and female students' skill in proposing a conjecture of the cosine law problem given was low. A study regarding the analysis of students' errors in mathematical reasoning in solving geometry problems showed that some students had difficulty expecting the correct conjecture (Setiawan \& Sa'dijah, 2020). It means that their skill to guess the correct conjecture is still low. The low skill of male and female students in proposing a conjecture could be shown from the analysis of the achievement of students' skill in solving cosine law problems. Eight male students had a high skill, and fifteen male students had a low skill in proposing a conjecture. It indicates that mostly male students still have difficulty solving the cosine law problem.

On the other hand, fourteen female students had a high skill, and twenty-five female students had a low skill in proposing a conjecture. It also indicates that most female students still have difficulty in solving the cosine law problem. However, some male and female students have been able to finish the cosine law problem well because they have a high skill in proposing a conjecture. Therefore, they can expect the correct conjecture and give the precise reason for the conjecture made, although some students give the less precise reason.

The distribution of male and female students' skills in proposing a conjecture of the cosine law problem is presented in Figure 4. The figure describes those three male students and seven female students who could guess the correct conjecture and give the proper reason. This shows that they have a high skill to propose a conjecture to decide precisely the type of catfish pond that has the vertex with the largest angle size. The evidence is presented in Figure 5. 


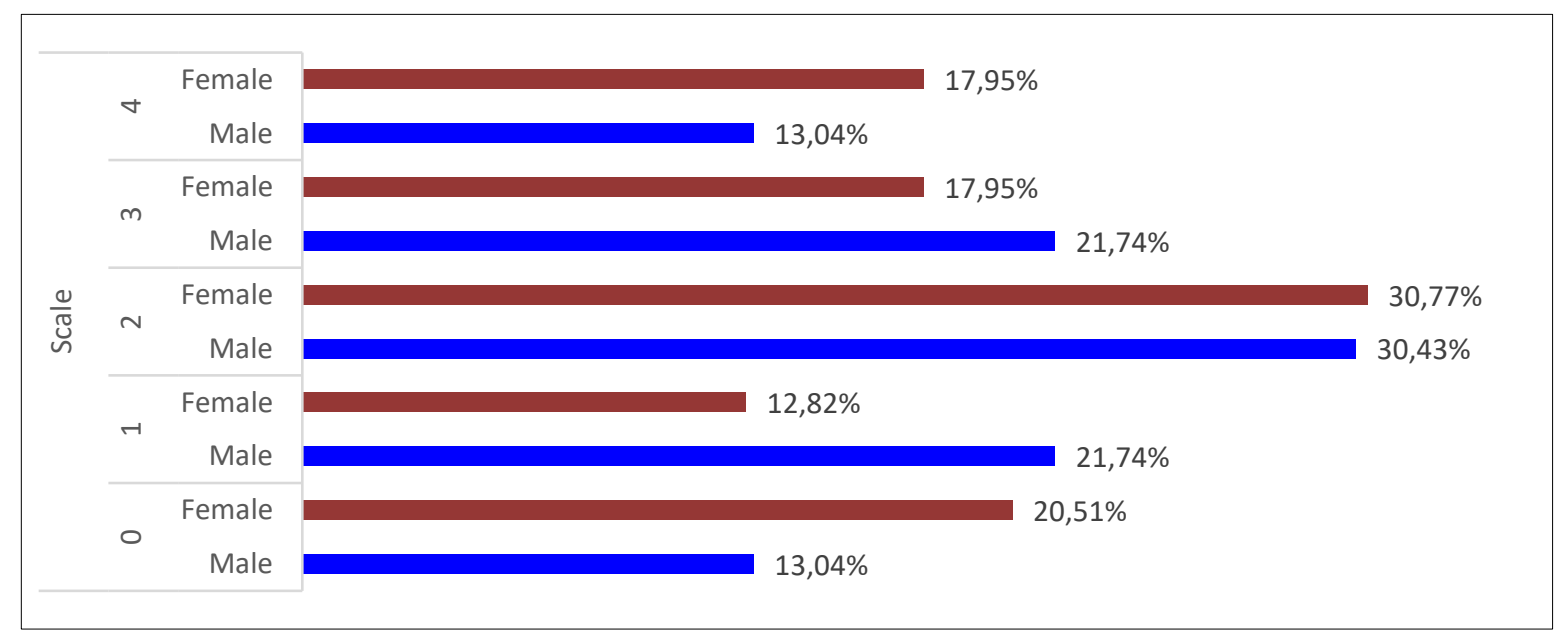

Figure 4. The distribution of students' skills in proposing a conjecture

(2)
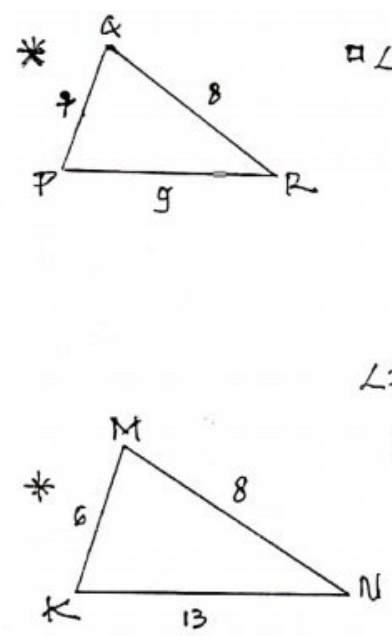

$$
\begin{aligned}
& \square \angle P=\frac{a^{2}+r^{2}-p^{2}}{2 a r} \square \angle Q=\frac{p^{2}+r^{2}-q^{2}}{2 p r} \text { I } \angle R=\frac{p^{2}+a^{2}-r^{2}}{2 p a} \\
& =\frac{9^{2}+t^{2}-8^{2}}{2 \cdot 9 \cdot 7}=\frac{8^{2}+t^{2}-9^{2}}{2 \cdot 8 \cdot 7}=\frac{8^{2}+9^{2}-t^{2}}{2 \cdot 8 \cdot 9} \\
& =\frac{66}{126}=\frac{52}{112}=\frac{96}{144}
\end{aligned}
$$

$$
\angle P<90^{\circ} \quad \angle Q<90^{\circ} \quad \angle R<90^{\circ}
$$

口 $\angle K=\frac{m^{2}+n^{2}-k^{2}}{2 m n}$ B $\angle M=\frac{k^{2}+n^{2}-m^{2}}{2 k n} \square \angle N=\frac{k^{2}+m^{2}-n^{2}}{2 k m}$

$$
=\frac{3^{2}+6^{2}-8^{2}}{2 \cdot 13 \cdot 6}=\frac{8^{2}+6^{2}-13^{2}}{2 \cdot 8 \cdot 6}=\frac{8^{2}+13^{2}-6^{2}}{2 \cdot 8 \cdot 13}
$$

$$
\begin{aligned}
& =\frac{133}{156}=\frac{-69}{96}=\frac{197}{208} \\
& \angle K<90^{\circ} \quad \angle M>90^{\circ} \quad \angle N<90^{\circ}
\end{aligned}
$$

yang uxumpunyai titik sudut dengan ukuran sudut terbesar terdapat pada kolam Beta yaitu titik M Karzna fitik M mrmilici suclut yang paling besar yaitu $>90^{\circ}$

\section{Translation:}

Pond Beta has vertex, $\mathrm{M}$, that has the largest angle, $>90^{\circ}$

Figure 5. The evidence of female students' answers in solving the cosine law problem

Seven female students and five male students could expect the correct conjecture and provide the reason for the conjecture, but the conjecture presented was less precise. It indicates that they have a moderate skill in proposing a conjecture so that although they can determine the type of catfish pond which has the vertex with the largest angle size, they present the less suitable reason. Furthermore, seven male students and twelve female students were able to expect the correct conjecture, but they could not provide a precise reason. Students were unable to give a precise reason because they did not understand the concept employed to explain the conjecture 
made. Some previous studies reported that some students still encountered misunderstanding concepts in trigonometry topics (Ahmad et al., 2018; Dewanto, Budiyono, \& Pratiwi, 2018; Hidayati, 2020). This indicates that they have a low skill to propose a conjecture. Therefore, they cannot provide a reason why they decide the type of catfish pond. The evidence is presented in Figure 6. Also, five male students and five female students proposed the incorrect conjecture. Moreover, eight female students and three male students did not answer the cosine law problem. These interpret that their skill to propose a conjecture is low. Therefore, they cannot determine the type of catfish pond which has the vertex with the largest angle size.

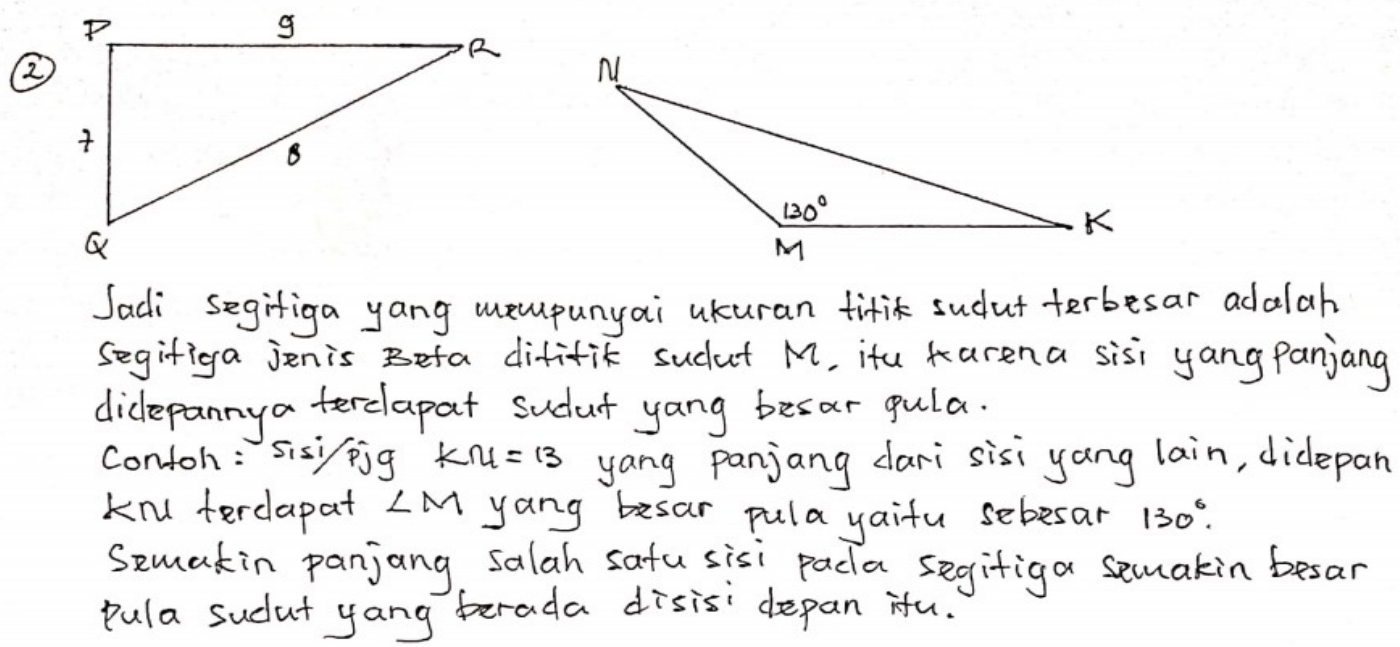

Translation:

So, the triangle with the largest angle is Beta, vertex $\mathrm{M}$, because the longer front side also has a large angle. For example, KM is 13 , which is longer than other sides. There is angle M, $130^{\circ}$. The longer a side of the triangle, the larger the angle located in front of the side.

Figure 6. The evidence of male students' answers in solving the cosine law problem

\section{Verifying the truth of a statement}

Table 7 shows that male and female students' skill in verifying the truth of a statement was moderate. It means that they still have a little difficulty solving the sine law problem. A previous study revealed that some students carried out errors in clarifying the truth of an argument in solving geometry problems (Setiawan \& Sa'dijah, 2020). It reveals that they have to enhance their critical thinking skills because it will support their ability to verify the truth of the argument (Bellamy, 2007). In addition, fifteen male students had a high skill, and eight male students had a low skill in clarifying the truth of an argument. This indicates that most male students can solve the sine law problem well, although some male students cannot solve the sine law problem. Meanwhile, there were twenty-one female students who had a high skill and eight teen female students who had a low skill in verifying the truth of an argument. It indicates that most female students can solve the sine law problem well. However, some female students are unable to solve it. Furthermore, male and female students who have a high skill to verify the truth of an argument can clarify the truth of Arman's statement claiming that the wooden beam can be used to cross the river. Whereas, they who have a low skill to clarify the truth of Arman's argument cannot state that the wooden beam can be employed to cross the river.

The distribution of male and female students' skills in verifying the truth of a statement is presented in Figure 7. Thirteen male students and ten female students applied the correct steps 
in the verification process, employed the correct principle and concept, and carried out the precise arithmetic operation. It indicates that they have a high skill to clarify the truth of an argument so that they can examine the truth of Arman's argument stating that the wooden beam can be used to cross over the river. The evidence is presented in Figure 8 and Figure 9.

Table 7. The results of students' MRS in verifying the truth of a statement

\begin{tabular}{lccccc}
\hline Gender & \multicolumn{2}{c}{ Descriptive statistics } & \multicolumn{2}{c}{$\begin{array}{c}\text { Mathematical reasoning } \\
\text { achievement }\end{array}$} \\
\cline { 2 - 6 } & Mean & Standard deviation & Sample size & Mean of percentage & Category \\
\hline Male & 2,78 & 1,57 & 23 & $69,57 \%$ & Moderate \\
Female & 2,28 & 1,38 & 39 & $57,05 \%$ & Moderate \\
\hline
\end{tabular}

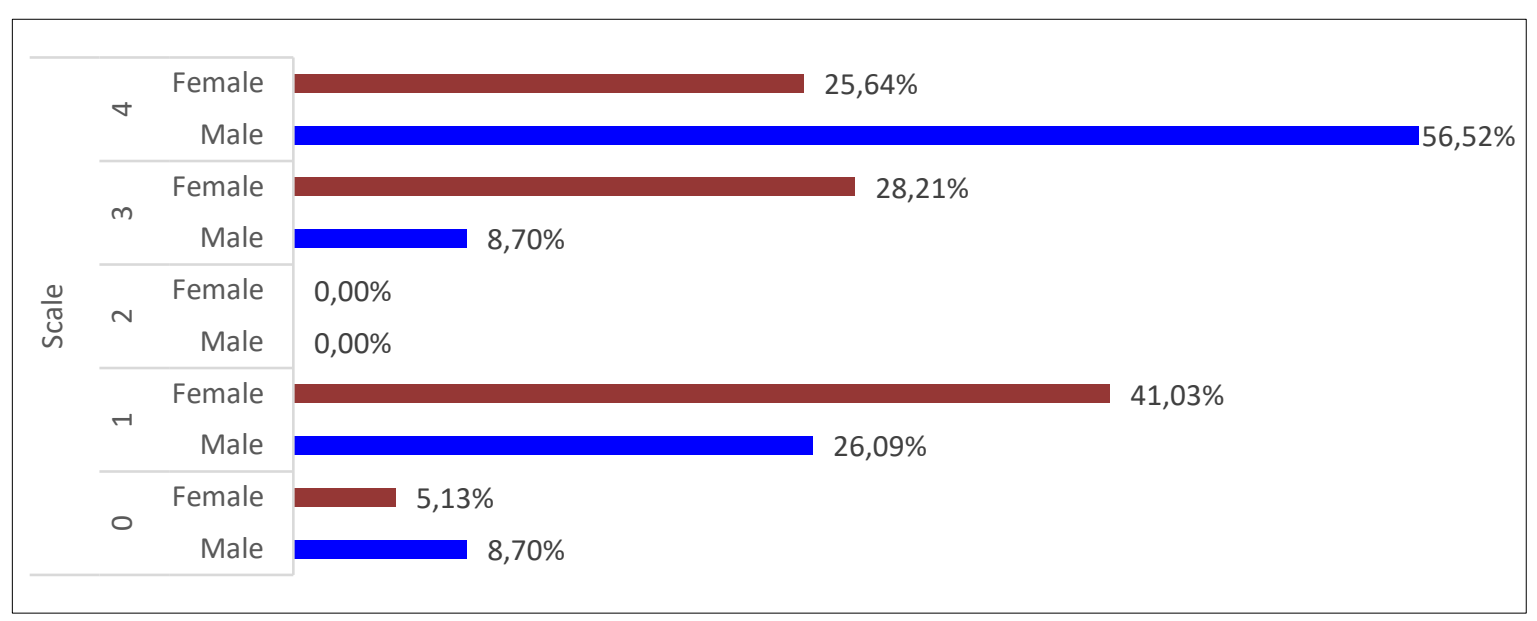

Figure 7. The distribution of students' skills in verifying the truth of a statement

Furthermore, eleven female students and two male students could apply the correct steps in the verification process and use the correct principle and concept. However, they conducted a less precise arithmetic operation. It means that they have a moderate skill in clarifying the truth of an argument. Some studies also revealed that students often made an error in the arithmetic operation (Hidayati, 2020; Usman \& Hussaini, 2017). Students' errors in arithmetic operations could be affected by students' difficulty in conducting basic arithmetic operations such as calculation or computation (Dewanto et al., 2018; Rohimah \& Prabawanto, 2019). As a consequence, there are some mistakes in the verification process that they carry out. In addition, six male students and sixteen female students applied the incorrect steps in the verification process. Moreover, two male students and two female students did not answer. These reveal that they have a low skill in verifying the truth of an argument. Therefore, they are unable to clarify the truth of Arman's argument stating that the wooden beam can be used to cross over the river. Students who have a low skill in clarifying the truth of an argument can be affected by some factors, such as misunderstanding the meaning of the problem (Ahmad et al., 2018; Dewanto et al., 2018; Hidayati, 2020; Wahyuni \& Widayanti, 2020) and misconceptions of a concept such as they are unable to establish the formula used (Ahmad et al., 2018; Dewanto et al., 2018; Hidayati, 2020; Rohimah \& Prabawanto, 2019; Satriani et al., 2020).

The result of the Mann-Whitney test showed that the p-value of $U$ statistics was 0,114 , and it was more than 0,05 . This result indicates that male and female students' skill to verify the truth 
of an argument in solving sine law problem is not different significantly. It could be revealed using the same achievement level of male and female students' skills to clarify the truth of an argument - which was moderate. Consequently, their skill in verifying the truth of Arman's argument stating that the wooden beam can be used to cross over the river is not significantly different. Descriptively, however, in solving the sine law problem, male students' skill to clarify the truth of an argument was higher than female students' skill to verify the truth of an argument. This finding was in line with a previous study (e.g., Salam \& Salim, 2020) that reported male students' skill was higher than female students' skill to validate the truth of an argument. Another study also revealed that female students made more mistakes than male students in checking the validity of an argument (Setiawan \& Sa'dijah, 2020). These prove that in verifying the truth of an argument, male students' skill is better than female ones.

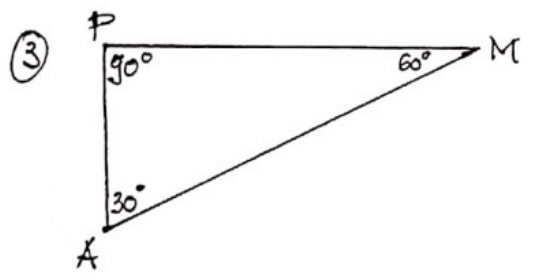

$$
\begin{aligned}
\frac{m}{\sin \alpha M} & =\frac{a}{\sin \alpha A} \text { karena punya kayu dan } 18 m \text { maka Amanda } \\
\frac{m}{\frac{m}{2} \sqrt{3}} & =\frac{A \sqrt{6}}{1 / 2} \text { bisa menyeberangi karena } \\
m & =A \sqrt{18} \text { jarak Farus ditempuh. } \\
m & =12 \sqrt{3} \\
& =18,92
\end{aligned}
$$

Translation:

Because having the wooden beam $18 \mathrm{~m}$ then Amanda can cross the river as the length of the wood equals the distance

Figure 8. The evidence of male students' answers in solving the sine law problem

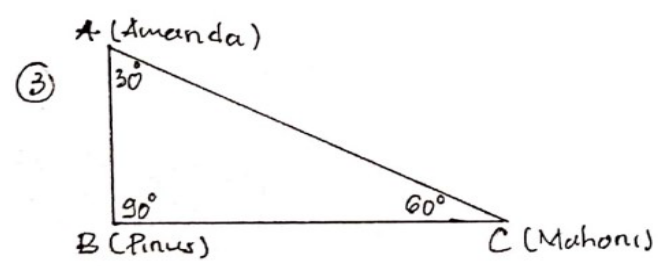

$$
\begin{aligned}
& B C \text { tigak hrus } A B \text { sehingga } \angle B=90^{\circ} \\
& \begin{aligned}
\angle C & =180^{\circ}-\left(90^{\circ}+30^{\circ}\right) \\
& =180^{\circ}-120^{\circ} \\
& =60^{\circ}
\end{aligned} \\
& \text { Misalkan lebar sungai } x \text {, maka } \\
& \frac{x}{\sin \angle C}=\frac{a}{\sin \angle A} \Leftrightarrow \frac{x}{\sin 60^{\circ}}=\frac{4 \sqrt{6}}{\sin 30^{\circ}} \\
& \frac{x}{\frac{x}{2} \sqrt{3}}=\frac{4 \sqrt{6}}{1 / 2} \Leftrightarrow x=12 \sqrt{2}
\end{aligned}
$$

Karena panjang kayu $18 \mathrm{~m}$ sedangkan lebar sungai $12 \sqrt{2}$. sadi Amanda bisa menyeberangi sungai tersebut karena Panjang kayu lebih besar daripada lebar sungai dan pernyataan

Translation:

Because the length of the wood is $18 \mathrm{~m}$ while the width of the river is $12 \sqrt{2}$, then Amanda can travel across the river as the wood is longer than the width of the river. Thus, Amanda's statement is correct.

Figure 9. The evidence of female students' answers in solving the sine law problem 


\section{Generalizing a statement}

Table 8 reveals that male and female students' skill in generalizing the statement was low. This means that most students are not able to solve the trigonometry function problem, specifically the cosine function. This result was similar to the previous study; Rodiah and Triyana (2019) revealed that students' skill in concluding was low in solving a two-variable linear equation system. Furthermore, all male students had a low skill to generalize the statement. Also, from thirty-nine female students, only one student had a high skill, and other female students had a low skill to generalize the statement. It can be interpreted that most students cannot determine the cosine function from some characteristics of function given because they have difficulty to give the reason toward the cosine function established and make a conclusion that it is the correct cosine function asked. Therefore, they have to improve their skill in generalizing the statement by the practice of mathematics problem that measures students' skill to conclude.

Table 8. The results of students' MRS in generalizing the statement

\begin{tabular}{lccccc}
\hline Gender & \multicolumn{2}{c}{ Descriptive statistics } & \multicolumn{2}{c}{$\begin{array}{c}\text { Mathematical reasoning } \\
\text { achievement }\end{array}$} \\
\cline { 2 - 6 } & Mean & Standard deviation & Sample size & Mean of percentage & Category \\
\hline Male & 0,83 & 0,39 & 23 & $20,65 \%$ & Low \\
Female & 0,64 & 0,63 & 39 & $16,03 \%$ & Low \\
\hline
\end{tabular}

The distribution of male and female students' skills in generalizing the statement is presented in Figure 10. It describes that one female student could make the correct generalization and conduct the slight error of the generalization process. It indicates that she has moderate skill in generalizing the statement. Consequently, she can determine the correct cosine function. However, the process to find the cosine function is a slight error, such as students' error to calculate or compute basic arithmetic operations. Several previous studies reported that students often carried out an error in calculating or conducting basic arithmetic operations (Dewanto et al., 2018; Hidayati, 2020; Rohimah \& Prabawanto, 2019; Usman \& Hussaini, 2017). The evidence is presented in Figure 11.

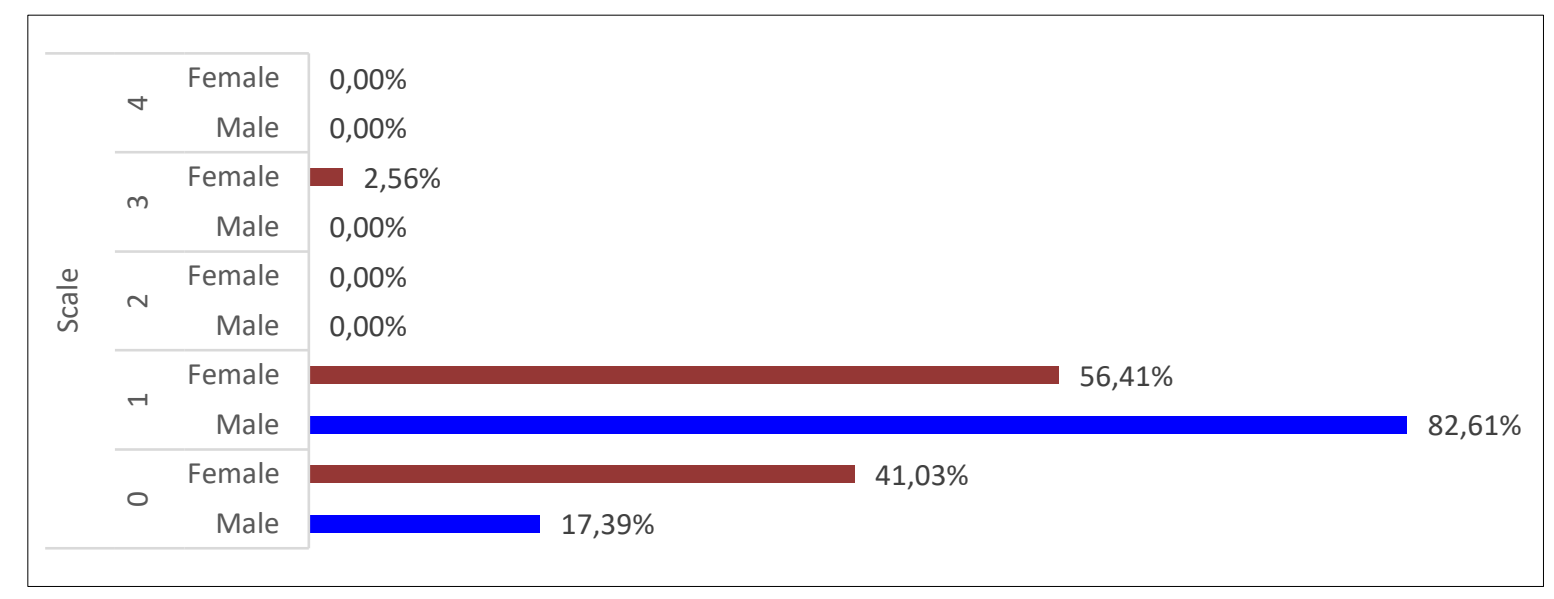

Figure 10. The distribution of students' skills in generalizing the statement 
Furthermore, nineteen male students and twenty-two female students made the incorrect generalization. The evidence is presented in Figure 12. Moreover, sixteen female students and four male students did not answer. This indicates that they have a low skill to generalize the statement. Therefore, they are unable to determine the correct cosine function asked. As a result, they cannot solve the trigonometry function problem. Students who had a low skill to generalize the statement could be caused several things: they did not elaborate and synthesize the characteristics of cosine function given, did not understand the concept of function, or did not understand the method for solving a two-variable linear equation system. Some previous studies revealed that most students still had a low skill to understand the principle and concept of mathematics, specifically trigonometry (Dewanto et al., 2018; Hidayati, 2020; Wahyuni \& Widayanti, 2020).

$$
\begin{aligned}
& \text { (4) Diket: }{ }^{*} g(x)=p \cos k x+b \quad \\
& \text { titik kurva: }(0, A) \text { dan }\left(\frac{\pi}{2},-2\right) * D_{g}=\left\{x \mid 0 \leq x \leq \frac{\pi}{2}\right\}
\end{aligned}
$$

Figure 11. The evidence female students' answers in solving trigonometry function

$$
\begin{aligned}
& \text { (4) }{ }^{*} D_{g}=\left\{x \mid 0 \leq x \leq \frac{\pi}{2}\right\} \text { * } R_{g}=\{y \mid-2 \leq y \leq 4\} \\
& \text { * } g(x)=P \cos k x+b \quad * 0<p<5 \\
& x=0 \text { dan } \pi / 2 \\
& y=4 \text { dan }-2 \\
& \text { * } g(x)=p \cos (k \cdot 0+r) \quad * g(x)=p \cos \left(k \cdot \frac{\pi}{2}+r\right) \\
& 4=p \cos (0+r) \quad-2 \simeq p \cos \left(\frac{k \pi}{2}+r\right) \\
& P=A \text { atan } \cos r=4 \quad P=-2 \text { atan } \cos \left(\frac{k \pi}{2}+r\right)=-2
\end{aligned}
$$

Figure 12. The evidence of male students' answers in solving trigonometry function 
The result of the Mann-Whitney test showed that the p-value of U statistics was 0,088 , and it was more than 0,05 . This result indicates that male and female students' skill to generalize the statement in solving the cosine function problem is not different significantly. It could be revealed that using the same achievement level of male and female students' skill to generalize the statement - which was low. Therefore, their skill in generalizing some characteristics of cosine function given to determine the cosine function asked is not different significantly. Descriptively, however, in solving the trigonometry function problem, specifically the cosine function, male students' skill to generalize the statement was higher than female students' skill to generalize the statement. A study regarding the analysis of students' errors on mathematical reasoning in solving geometry problems reported that female students carried out more mistakes than male students in concluding (Setiawan \& Sa'dijah, 2020). Meanwhile, several previous studies revealed that in concluding, female students' skill was higher than male students' skill (Rodiah \& Triyana, 2019; Salam \& Salim, 2020). It uncovers that male and female students' skill in generalizing the statement is not different significantly.

\section{Conclusion, implication, and limitation}

Overall, this study found that male and female students' MRS in solving trigonometry problems was low. Specifically, male and female students' skills in finding a relationship pattern, proposing a conjecture, and generalizing the statement were also low. Only in verifying the truth of an argument, male and female students' skills were moderate. Furthermore, the MRS of male and female students did not differ significantly. Moreover, male and female students' skills to find a relationship pattern, propose a conjecture, verify the truth of an argument, and generalize the statement were also not significantly different. Therefore, overall, they had the same opportunity to enhance or improve their MRS.

This study implies that mathematics teachers in secondary schools should enhance male and female students' MRS, specifically on the indicator of finding a relationship pattern, proposing a conjecture, and generalizing a statement because the achievement of male and female students' MRS on those indicators is low. The enhancement of male and female students' MRS in trigonometry topics can be carried out by supporting male and female students' basic concepts and principles in trigonometry identity, sine, and cosine law, and trigonometry function. The improvement of these basic and principle of trigonometry topics of male and female students can be conducted by implementing the precise model or approach of mathematics learning such as problem-based learning model or realistic mathematics education approach. Since the mathematics learning model or approach will accommodate male or female students to learn trigonometry topics collaboratively, they can share information between male or female students regarding the precise concept or principle of trigonometry to solve trigonometry problems. Therefore, the findings of this study provide a starting point for improving male and female students' MRS in mathematics learning by solving trigonometry problems specifically.

This study only involved four indicators of MRS. To explore overall male and female MRS, we recommend involving other MRS indicators for further research. Also, the sub-topic of trigonometry involved in this study is half of the trigonometry topic. Other researchers can involve some sub-topics of trigonometry in further research, such as trigonometry equation and trigonometry inequality. In addition, the time for students to solve trigonometry problems in this study is limited. It is only one hour, so it is difficult for students to manage their work in solving 
trigonometry problems because the proportion between the difficulty level of problems and the given time is not balanced.

\section{Acknowledgment}

The authors would like to thank the Indonesian Endowment Fund of Education (LPDP) for funding the research.

\section{References}

Ahmad, H., Febryanti, F., Muthmainnah, M., Yakin, A. Al, \& Sarbi, S. (2018). The analysis of student error in solve the problem of spherical trigonometry application. Journal of Physics: Conference Series, 1114(012114), 1-9. Doi: 10.1088/1742-6596/1114/1/012114

Altiner, E. C., \& Dogan, M. C. (2018). Investigating the spatial reasoning skills of students in the context of mathematical thinking profiles. European Journal of Education Studies, 4(11), 26-38. Doi: 10.5281 /zenodo. 1318323

Bellamy, C. (2007). Online democratic deliberation in a time of information abundance. Fast Capitalism, 2(2), 121-126. Doi: 10.32855/fcapital.200701.011

Bieda, K. N., Ji, X., Drwencke, J., \& Picard, A. (2014). Reasoning-and-proving opportunities in elementary mathematics textbooks. International Journal of Educational Research, 64, 71-80. Doi: 10.1016/j.ijer.2013.06.005

Bjuland, R. (2007). Adult students' reasoning in geometry: Teaching mathematics through collaborative problem-solving in teacher education. The Mathematics Enthusiast, 4(1), 1-30. Retrieved from https://scholarworks.umt.edu/tme/vol4/iss1/1/

Boone, H. N., \& Boone, D. A. (2012). Analyzing Likert data. Journal of Extension, 50(2), 1-5.

Brandell, G., Leder, G., \& Nyström, P. (2007). Gender and mathematics: Recent development from a Swedish perspective. ZDM, 39, 235-250. Doi: 10.1007/s11858-007-0025-4

Brandell, G., \& Staberg, E. M. (2008). Mathematics: A female, male or gender-neutral domain? A study of attitudes among students at the secondary level. Gender and Education, 20(5), 495-509. Doi: $10.1080 / 09540250701805771$

Breen, S., \& O'Shea, A. (2011). The use of mathematical tasks to develop mathematical thinking skills in undergraduate calculus courses - A pilot study. Proceedings of the British Society for Research into Learning Mathematics, pp. 43-48. Retrieved from https://mural.mynoothuniversity.ie/4905/

Brown, J. D. (2011). Likert items and scales of measurement? SHIKEN: JALT Testing \& Evaluation SIG Newsletter, 15(1), 10-14. Retrieved from https://hosted.jalt.org/test/bro 34.htm

Buckley, J., Seery, N., \& Canty, D. (2019). Investigating the use of spatial reasoning strategies in geometric problem-solving. International Journal of Technology and Design Education, 29(2), 341362. Doi: $10.1007 / \mathrm{s} 10798-018-9446-3$

Chang, C.-Y. (2010). Does problem-solving = prior knowledge + reasoning skills in earth science? An exploratory study. Research in Science Education, 40(2), 103-116. Doi: 10.1007/s11165-008-9102-0

de Gois, G., de Oliveira-Júnior, J. F., da Silva Junior, C. A., Sobral, B. S., de Bodas Terassi, P. M., \& Junior, A. H. S. L. (2020). Statistical normality and homogeneity of a 71-year rainfall dataset for the state of Rio de Janeiro-Brazil. Theoretical and Applied Climatology, 141(3-4), 1573-1591. Doi: 10.1007/s00704-020-03270-9

De Winter, J. F. C., \& Dodou, D. (2010). Five-point Likert items: t-test versus Mann-Whitney-Wilcoxon (Addendum added October 2012). Practical Assessment, Research, and Evaluation, 15(11), 1-16. Doi: $10.7275 / \mathrm{bj} 1 \mathrm{p}$-ts64

Dewanto, M. D., Budiyono, B., \& Pratiwi, H. (2018). Students' error analysis in solving the math word problems of high order thinking skills (HOTS) type on trigonometry application. Proceeding of the $1^{\text {st }}$ Annual International Conference on Mathematics, Science, and Education (ICoMSE 2017), pp.195200. Doi: 10.2991/icomse-17.2018.34 
Dhlamini, Z. B., Chuene, K., Masha, K., \& Kibirige, I. (2019). Exploring grade nine geometry spatial mathematical reasoning in the South African annual national assessment. Eurasia Journal of Mathematics, Science and Technology Education, 15(11), 1-17. Doi: 10.29333/ejmste/105481

Erdem, E., \& Soylu, Y. (2017). Age and gender-related change in mathematical reasoning ability and some educational suggestions. Journal of Education and Practice, 8(7), 116-127. Retrieved from https://eric.ed.gov/?id=EJ1137539

Ersoy, E., \& Bal-İncebacak, B. (2017). Mathematical reasoning skills of 7th-grade students. International Online Journal of Educational Sciences, 9(1), 262-275. Doi: 10.15345/iojes.2017.01.018

Fay, M. P., \& Proschan, M. A. (2010). Wilcoxon-Mann-Whitney or T-test? On assumptions for hypothesis tests and multiple interpretations of decision rules. Statistics Surveys, 4, 1-39. Doi: 10.1214/09-SS051

Gall, M. D., Gall, J. P., \& Borg, W. R. (2003). Educational Research: An Introduction (7th edition.). Pearson Education, Inc.

Gliem, J. A., \& Gliem, R. R. (2003). Calculating, interpreting, and reporting Cronbach's alpha reliability coefficient for Likert-type scales. Proceedings of the Midwest Research to Practice Conference in Adult, Continuing, and Community Education, pp.82-88. Doi: 10.1016/B978-0-444-88933-1.500234

Goel, S., \& Elstak, I. R. (2015). Reform of teaching a trigonometry course. Georgia Journal of Science, 73(2), 136-146.

Gorbunova, A. A., \& Lemeshko, B. Y. (2012). Application of parametric homogeneity of variances tests under violation of classical assumption. Paper presented at the 2nd Stochastic Modeling Techniques and Data Analysis International Conference. Retrieved from https://www.researchgate.net/publication/236162433_Application_of_Parametric_Homogeneity_of_ Variances_Tests_under_Violation_of_Classical_Assumption

Hidayati, U. (2020). Analysis of students' errors in solving trigonometry problems. Journal of Mathematics Education, 5(1), 54-60. Doi: 10.31327/jme.v5i1.1181

Kadarisma, G., Nurjaman, A., Sari, I. P., \& Amelia, R. (2019). Gender and mathematical reasoning ability. Journal of Physics: Conference Series, 1157(042109), 1-7. Doi: 10.1088/1742$6596 / 1157 / 4 / 042109$

Karunika, A. M., Kusmayadi, T. A., \& Fitrana, L. (2019). Profile of mathematical reasoning ability of female students based on self-efficacy. Journal of Physics: Conference Series, 1265(012008), 1-9. Doi: 10.1088/1742-6596/1265/1/012008

Marchis, I. (2013). Pre-service primary school teachers' logical reasoning skills. Acta Didactica Napocensia, 6(4), 59-66. Retrieved from https://eric.ed.gov/?id=EJ1053714

Maya, R. (2011). Pengaruh pembelajaran dengan metode MOORE termodifikasi terhadap pencapaian kemampuan pemahaman dan pembuktian matematik mahasiswa [The effect of learning with modified MOORE method on the achievement of mathematical understanding and proof of college students]. Disertasi UPI: Tidak Diterbitkan.

McElduff, F., Cortina-Borja, M., Chan, S. K., \& Wade, A. (2010). When t-tests or Wilcoxon-MannWhitney tests won't do. American Journal of Physiology - Advances in Physiology Education, 34(3), 128-133. Doi: 10.1152/advan.00017.2010

Mendick, H. (2005). A beautiful myth? the gendering of being/doing "good at maths." Gender and Education, 17(2), 203-219. Doi: 10.1080/0954025042000301465

Misu, L., Hasnawati, \& Rahim, U. (2019). Analysis of mathematical ability based on gender. Journal of Physics: Conference Series, 1188(012054), 1-5. Doi: 10.1088/1742-6596/1188/1/012054

Morris, A. K. (2002). Mathematical reasoning: Adults' ability to make the inductive-deductive distinction. Cognition and Instruction, 20(1), 79-118. Doi: 10.1207/S1532690XCI2001_4

NCTM. (2000). Principles and standards for school mathematics. The National Council of Teachers of Mathematics, Inc.

Rasch, D., Kubinger, K. D., \& Moder, K. (2011). The two-sample t-test: Pre-testing its assumptions does not pay off. Statistical Papers, 52(1), 219-231. Doi: 10.1007/s00362-009-0224-x

Rich, K., \& Brendefur, J. L. (2019). The importance of spatial reasoning in early childhood mathematics. In Early Childhood Education. Intech Open. Doi: 10.5772/intechopen.73467

Rodiah, S., \& Triyana, V. A. (2019). Analisis kemampuan penalaran matematis siswa kelas IX MTs pada materi sistem persamaan linear dua variabel berdasarkan gender [Analysis of mathematical reasoning skills of ninth-grade students on the topic of two variable linear equation system based on gender]. 
Jurnal Kajian Pembelajaran Matematika, 3(1), 1-8. Retrieved from http://journal2.um.ac.id/index.php/jkpm/article/view/6262

Rohimah, S. M., \& Prabawanto, S. (2019). Student's difficulty identification in completing the problem of equation and trigonometry identities. International Journal of Trends in Mathematics Education Research, 2(1), 34-36. Doi: 10.33122/ijtmer.v2i1.50

Rokhima, W. A., Kusmayadi, T. A., \& Fitriana, L. (2019). Mathematical reasoning of students in senior high school based on gender differences. Journal of Physics: Conference Series, 1318(012092), 1-6. Doi: 10.1088/1742-6596/1318/1/012092

Rosdiana, Budayasa, I. K., \& Lukito, A. (2019). Pre-service primary school teachers' mathematical reasoning skills from gender perspectives: A case study. Journal for the Education of Gifted Young Scientists, 7(4), 1107-1122. Doi: 10.17478/jegys.620234

Salam, M., \& Salim, S. (2020). Analysis of mathematical reasoning ability (MRA) with the discovery learning model in gender issues. Journal of Educational Science and Technology (EST), 6(2), 137150. Doi: $10.26858 /$ est.v6i2.13211

Sartika, I., \& Fatmanissa, N. (2020). Analysis of students' error in solving trigonometric function problems which assess higher-order thinking skills. Contemporary Mathematics and Science Education, 1(1), 1-10. Doi: 10.30935/conmaths/8437

Satriani, S., Wahyuddin, Halim, N. H., \& Syamsuadi, A. (2020). The analysis of compliance type students error in resolving the integral challenge of trigonometry function. International Journal of Mathematics Trends and Technology, 66(10), 14-19. Doi: 10.14445/22315373/ijmtt-v66i10p503

Setiawan, A., \& Sa'dijah, C. (2020). Analysis of students' errors in mathematical reasoning on geometry by gender. Journal of Disruptive Learning Innovation, 1(2), 59-66.

Shelby, L. B. (2011). Beyond Cronbach's Alpha: Considering confirmatory factor analysis and segmentation. Human Dimensions of Wildlife: An International Journal, 16(2), 142-148. Doi: $10.1080 / 10871209.2011 .537302$

Sullivan, G. M., \& Artino, A. R. (2013). Analyzing and interpreting data from Likert-type scales. Journal of Graduate Medical Education, 5(4), 541-542. Doi: 10.4300/jgme-5-4-18

Suparman, S., Juandi, D., \& Herman, T. (2021). Achievement emotions of female students in mathematical problem-solving situations. Journal of Physics: Conference Series, 1806(012106), 1-8. Doi: $10.1088 / 1742-6596 / 1806 / 1 / 012106$

Usman, M. H., \& Hussaini, M. M. (2017). Analysis of students' error in learning trigonometry among senior secondary school students in Zaria Metropolis, Nigeria. IOSR Journal of Mathematics, 13(2), 1-4. Doi: 10.9790/5728-1302040104

Vaske, J. J., Beaman, J., \& Sponarski, C. C. (2016). Rethinking internal consistency in Cronbach's Alpha. Leisure Sciences: An Interdisciplinary Journal, 39(2), 163-173. Doi: 10.1080/01490400.2015.1127189

Wahyuni, N. S., \& Widayanti, E. (2020). Students' errors analysis in finishing a problem-solving test based on Newman procedures in trigonometry materials. IndoMath: Indonesia Mathematics Education, 3(2), 78. Doi: 10.30738/indomath.v3i2.7213

Wong, T. T.-Y. (2017). Is conditional reasoning related to mathematical problem-solving? Developmental Science, 21(5), 1-12. Doi: 10.1111/desc.12644

Yates, L. (1997). Gender equity and the boys' debate: What sort of challenge is it? British Journal of Sociology of Education, 18(3), 337-347. Doi: 10.1080/0142569970180302

Yildirim, S. (2000). Effects of an educational computing course on preservice and in-service teachers. Journal of Research on Computing in Education, 32(4), 479-495. Doi: 10.1080/08886504.2000.10782293 